\title{
Cikkismertetés: Vajon a tejtermékek fogyasztása csökkenti a szív- és érrendszeri betegségek kockázatát és az ebből adódó halálozást?
}

\author{
Article review: Does consumption of dairy products reduce the risk of \\ cardiovascular disease and mortality?
}

Ismertető: $\quad$ Erdei Gergő $\square$

Országos Gyógyszerészeti és Élelmezés-egészségügyi Intézet

Ismertetett cikk: Dehghan M, Mente A, Rangarajan S et al. Association of dairy intake with cardiovascular disease and mortality in 21 countries from five continents (PURE): a prospective cohort study. Lancet. 2018 Nov 24;392(10161):2288-2297. doi: 10.1016/S0140-6736(18)31812-9

Beküldve: $\quad$ 2019. 01. 09.

doi: $\quad$ 10.24365/ef.v60i2.399

Kulcsszavak: tejtermékek; szív- és érrendszeri betegségek; mortalitás; követéses vizsgálat; agyvérzés

Keywords: dairy products; cardiovascular diseases; mortality; prospective cohort study; stroke

\section{HÁTTÉR}

A táplálkozási ajánlások szerint érdemes minimalizálni a magas zsírtartamú tejtermékek fogyasztását, mivel ezek telített zsírsavtartalmuk miatt növelhetik a vérben lévő lipidek szintjét, valamint a szív- és érrendszeri betegségek előfordulásának gyakoriságát és az ebből adódó halálozást. Mivel az alacsony és közepes jövedelmi szintű országokból kevés adat áll rendelkezésünkre a tejtermékek fogyasztásának gyakorisága és az egészségi állapot közötti összefüggésekről, így jelen kutatás célja az volt, hogy ezekben az országokban felmérjék az egyes tejés tejtermékfajták fogyasztási gyakorisága közötti kapcsolatot a szív- és érrendszeri betegségek kockázatával, illetve az ezekből adódó halálozás gyakoriságával.

\section{MÓDSZER}

A "The Prospective Urban Rural Epidemiology (PURE)" tanulmány követéses vizsgálat volt, amely 35-70 éves személyek részvételével zajlott 5 kontinens 21 országában. A vizsgálatban 136384 fő élelmiszerfogyasztási gyakoriság kérdőívének (Food Frequency Questionnaire) eredményét értékelték. A tanulmány elsődleges célja az, hogy értékelje a tejtermékek fogyasztása - ide értve a tejet, joghurtot, sajtot - valamint a szív- és érrendszeri megbetegedések és a halálozás közötti összefüggést. 


\section{EREDMÉNYEK}

Az eredmények alapján a tejtermékek jelentős bevitele ( $>2$ adag/nap, szemben a 0 adag/nappal) alacsonyabb kockázatot jelent többek között a teljes halálozás (kockázati arány 0,83, 95\%-os hitelesség mellett 0,72-0,96; $p=0,0052)$, a főbb szív- és érrendszeri betegségek (kockázati arány 0,78, 95\%os hitelesség mellett 0,67-0,90; $p=0,0001$ ), és az agyvérzés (kockázati arány 0,66, 95\%-os hitelesség mellett 0,53-0,82; $p=0,0003$ ) esetében. Ugyanakkor nem figyelhető meg szignifikáns összefüggés a szívinfarktus esetében (kockázati arány 0,89, 95\%os hitelesség mellett $0,71-1,11 ; p=0,163)$. Az eredmények között említik, hogy a vajbevitel alacsony volt és nem mutat szignifikáns összefüggést a klinikai kimenetelekkel (kockázati arány 1,09, 95\%-os hitelesség mellett 0,90-1,33; $p=0,4113$ ). Jelen vizsgálat eredményei azt mutatják, hogy a tejtermékek jelentős bevitele alacsony kockázatot jelent a halálozással, szív- és érrendszeri betegségekkel kapcsolatban, különös tekintettel az agyvérzésre.

\section{TANULSÁGOK A HAZAI SZAKEMBEREK SZÁMÁRA}

Jelen vizsgálat, összhangban hazai és nemzetközi táplálkozástudományi ajánlásokkal, javasolja a tej és a tejtermékek fogyasztásának növelését. A tanulmány felhívja a figyelmet arra, hogy különösen az alacsony és közepes jövedelemmel rendelkezők csoportjában szükséges a tej és tejtermékek fogyasztásának növelése, ahol a beviteli mennyiségek jóval a javasolt fogyasztási mennyiségek alatt vannak. 